\title{
Notes on the Sepsidae (Diptera) from India, with description of a new species ${ }^{1-3)}$
}

\author{
Mitsuhiro IWASA ${ }^{4)}$ and Raghav Ram TEWARI ${ }^{5)}$ \\ ${ }^{4)}$ Laboratory of Entomology, Obihiro University of Agriculture and Veterinary Medicine, \\ Obihiro, Hokkaido 080, Japan \\ ${ }^{5)}$ Department of Zoology, University of Allahabad, Allahabad-211002, India
}

(Recieved: October 3, 1994)

\begin{abstract}
Nineteen species belonging to seven genera of Sepsidae are recorded from India. Of them, Meroplius maximus n. sp. is described and Meroplius elephantis Iwasa, Perochaeta hennigi Ozerov and Dicronosepsis prominula Iwasa are newly recorded from India.
\end{abstract}

Key words: Diptera, Sepsidae, new species, new records, India.

\section{INTRODUCTION}

The Sepsidae of the Southwest Asia has been reported from India (Brunetti, 1909; Duda, 1926; Zuska, 1974, 1977; Iwasa, 1982; Iwasa and Tewari, 1990), Nepal (Zuska, 1968; Iwasa, 1984, 1994), Pakistan (Iwasa, 1989), Bangladesh (Iwasa et al., 1991) and Sri Lanka (Ozerov, 1992; Iwasa and Jayasekera, 1994). Up to the present, 7 genera and 20 species have been known from India, however the knowledge is insufficient.

In the course of the dipterous survey in Indian subcontinent in 1987 and 1993, we got some new materials of the Indian species of Sepsidae. In the present paper, we describe a new species and record 18 species including 3 newly recorded species.

\section{Saltella setigera Brunetti, 1909}

Saltella setigera Brunetti, 1909, Rec. Ind. Mus., 3: 368.

Specimens examined. 10 , Allahabad, Uttar Pradesh, 3-4 Sept. 1987, R. R. Tewari; 3q, Jabalpur to Piparia, Madhya Pradesh, 13-14 Sept. 1987, M. Iwasa.

Distribution. India, Nepal and Bangladesh.

1) Contribution No. 162 from the Laboratory of Entomology, Obihiro University of Agriculture and Veterinary Medicine.

2) This study was supported by the Grant-in-Aid for Monbusho International Scientific Research Program (Field Research) to Tokyo Medical and Dental University in 1993 (Grant No. 04041043)

3) This study was supported by the Grant-in-Aid for Monbusho International Scientific Research Program (Field Research) to Toyama Medical and Pharmaceutical University in 1987 (Grant No. 62041036). ZDSA Series No. 28.

4) 岩佐光啓：带広畜産大学畜産環境科学科昆虫学教室（ $\bar{T} 080$ 帯広市稲田町西 2 線） 


\section{Toxopoda contracta (Walker, 1853)}

Calobata? contracta Walker, 1853, Ins. Saundersiana, 4: 395.

Toxopoda contracta: Vanschuytbroeck, 1962, Inst. r. Sci. nat. Belg. Bull., 38: 6.

Specimens examined. 1 6 , Bangriposhi (200-380 m), Orissa, 24 Sept. 1993; M. Iwasa; 2ð, Amarkantak, Jabalpur, Madhya Pradesh, 8 Sept. 1987, M. Iwasa.

Distribution. Pakistan, India, Bangladesh and Sri Lanka.

\section{Meroplius beckeri (De Meijere, 1906)}

Sepsis beckeri De Meijere, 1906, Annl. Mus. natn. hung., 4: 185.

Meroplius beckeri: Duda, 1926, Annl. naturhist. Mus. Wien, 40: 49.

Specimens examined. 5ð̋, Astrang, Orissa, 28 Sept. 1993, M. Iwasa.

Distribution. India (Bihar, Maharashtra and Orissa), Bangladesh and Nepal.

\section{Meroplius elephantis Iwasa, 1994}

Meroplius elephantis Iwasa, 1994, Jpn. J. Ent., 62: 164.

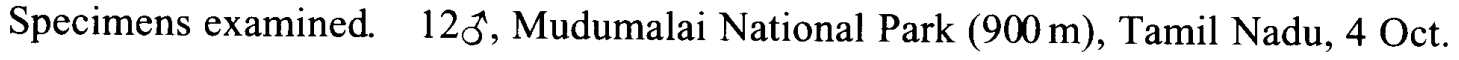
1994, M. Iwasa; 8 đ̆, Nagarahole National Park (720 m), Karnataka, 10 Oct. 1993, M. Iwasa.

Distribution. Thailand and India (Tamil Nadu and Karnataka). New to India.

\section{Meroplius maximus Iwasa, $\mathrm{n}$. $\mathrm{sp}$.}

(Figs. 1-4)

Male. Head: eyes brown; frons black and shining; face and gena dark brown; occiput black and subshining; antennal segments dark brown; arista black and bare; vibrissal angle with 1 developed seta; genal lower margin with 12-14 peristomal setae in a line; 1 oc, 1 or (small), 1 vti, 1 vte, 1 pvt.

Thorax: wholly black; mesonotum, humeral callus and propleuron subshining; mesopleuron and pteropleuron shining; sternopleuron anteriorly shining and posteriorly pruinose; hypopleuron, metapleuron and metanotum shining to subshining; $1 \mathrm{~h}, 1 \mathrm{n}, 1 \mathrm{sa}$, $1 p a, 1 m, 1$ ap sc; $b s c$ absent.

Wings: hyaline, slightly tinged with brown; veins brown; humeral cell light brown; alula without a distinct postero-distal lobe and with microtrichia marginally; halteres yellow, darkened basally.

Legs: coxae and trochanters yellow; fore femur yellow with two stout ventral spines at distal one-third, distal one spatulate and inner one slender and pointed (Fig. 1); middle and hind femora yellow in basal half and dark brown in distal half; fore tibia yellow and ventrally with 1 moderate and 2 short setae at near basal one-third (Fig. 1); middle and hind tibiae dark brown; 1st and 2nd tarsal segments yellow and 3rd to 5th segments dark brown in fore and 

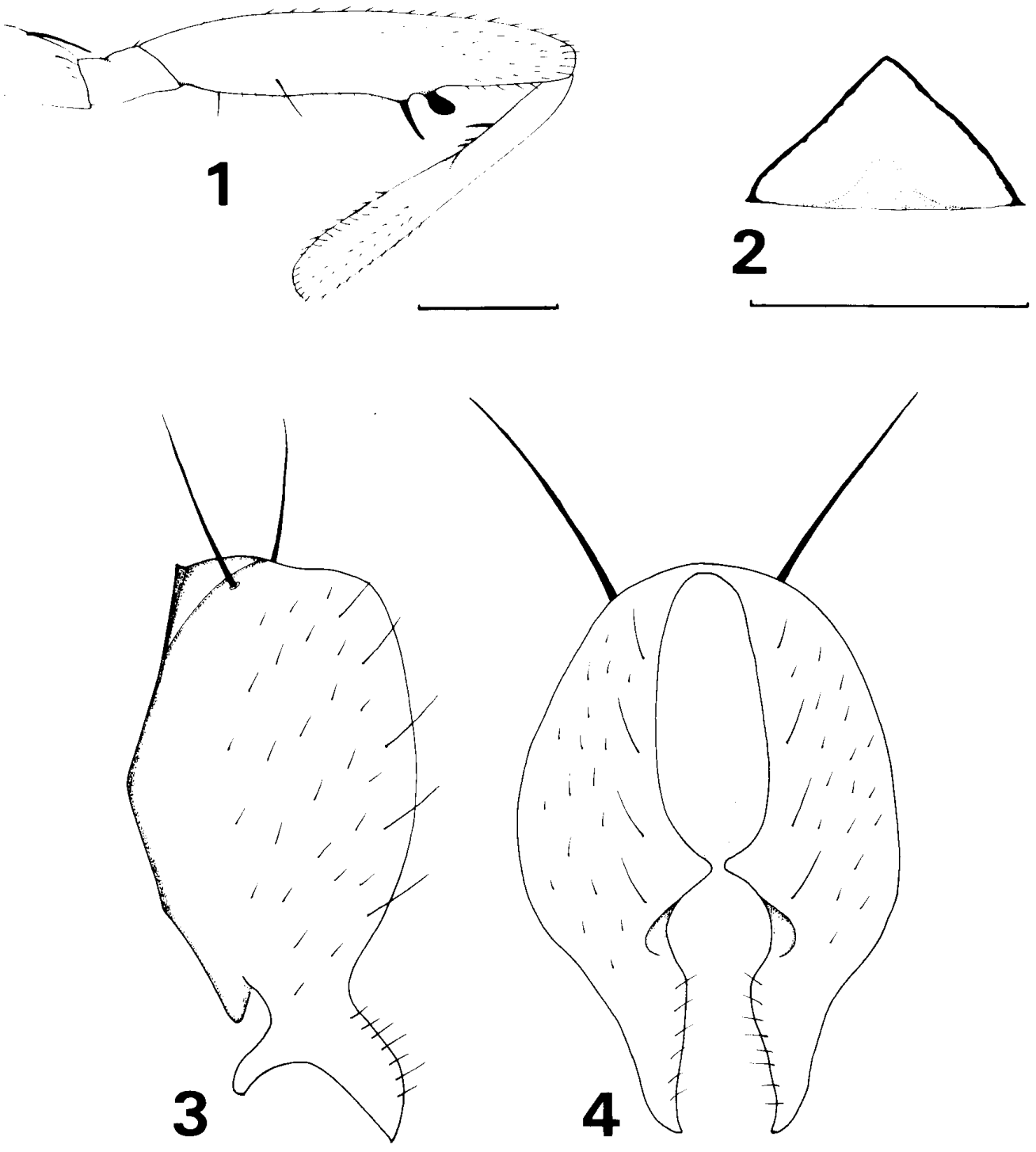

Figs. 1-4. Meroplius maximus Iwasa, n. sp.-1, male fore femur and tibia, anterior view (left); 2 , male 4th sternite; 3, male genitalia, lateral view (left); 4, ditto, posterior view. Scales: $0.25 \mathrm{~mm}$.

middle legs; hind tarsi brown.

Abdomen: tergites black, shining and sparsely with short bristles; 2 nd and 3rd sternites long, and 4th sternite triangular-shaped (Fig. 2); epandrium large and stout (Figs. 3-4); surstylus with stout projection anteriorly (Fig. 3).

Body length: ô, 3-4 mm; wing length, $3 \mathrm{~mm}$.

Female: Unknown.

Holotype $\widehat{\delta}$, Nagarahole National Park, Karnataka, India, 10 Oct. 1993, M. Iwasa (preserved in Obihiro University of Agriculture and Veterinary Medicine, Obihiro, Hokkaido, Japan). Paratypes: $8 \hat{\jmath}$, same data as holotype; $3 \hat{\jmath}$, Mudumalai National Park, Tamil Nadu, India, 4 Oct. 1994, M. Iwasa ( a part of paratypes will be preserved in University of Allahabad, 
India).

Distribution. India (Tamil Nadu).

Remarks. This species is closely related to M. beckeri (De Meijere) and M. elephantis Iwasa, but differs from them in the characteristics of male fore femur and surstylus.

\section{Meroplius fasciculatus (Brunetti, 1909)}

Sepsis fasciculatus Brunetti, 1909, Rec. Ind. Mus., 3: 365.

Meroplius fasciculatus: Zuska, 1972, Acta ent. bohemoslov., 69: 64

Specimens examined. $1 \delta^{\widehat{T}}$, Nandi Hills (1,490 m), Bangalore, Karnataka, 14 Oct. 1993, M. Iwasa; 1ðð, Wynad National Park (720 m), Kerala, 11 Oct. 1993, M. Iwasa;6ð̋, Amarkantak, Jabalpur, Madhya Pradesh, 9 Sept. 1987, M. Iwasa.

Distribution. Oriental Region and Japan.

\section{Perochaeta hennigi Ozerov, 1992}

Perochaeta hennigi Ozerov, 1992, Bull. Moscow Soc. naturalists, Biol. ser., 97: 44.

Specimens examined. $60^{\circ}$, Naduvattum $(1,400 \mathrm{~m})$, Tamil Nadu, India, 7 Oct. 1993, M. Iwasa; $10 ð$, Gudalur (1,200 m), Tamil Nadu, 7-8 Oct. 1993, M. Iwasa; $1 \precsim$, Dodabetta $(2,590 \mathrm{~m})$, Tamil Nadu, 8 Oct. 1993, M. Iwasa.

Distribution. Sri Lanka and India (Tamil Nadu). New to India.

Sepsis albopunctata Lamb, 1914

Sepsis albopunctata Lamb, 1914, Trans. Linn. Soc. Lond., 2: 323.

Specimens examined. 3ð, Mudumalai National Park, Tamil Nadu, 4 Oct. 1993, M. Iwasa; $1 \delta^{\jmath}$, Gudalur (1,400 m), Tamil Nadu, 9 Oct. 1993, M. Iwasa; $1{ }^{\jmath}$, Bangriposhi (380 m), Orissa, 25 Sep. 1993, M. Iwasa.

Distribution. Widely distributed in the Oriental, Afrotropical and Australasian Regions.

Sepsis coprophila de Meijere, 1906

Sepsis coprophila de Meijere, 1906, Ann. Mus. natn. hung., 4: 176.

Specimens examined. $8 \delta$, Nagarahole National Park, Karnataka, 10-11 Oct. 1993, M. Iwasa; 4ð, Mudumalai National Park, Tamil Nadu, 4 Oct. 1993, M. Iwasa;1 $\precsim$, Nandi Hills (1,490 m), Bangalore, Karnataka, 14 Oct. 1993, M. Iwasa.

Distribution. Widely distributed in the Oriental Region.

Sepsis indica Wiedemann, 1824

Sepsis indica Wiedemann, 1824, Analecta Ent.: 57.

Specimens examined. $12 ð$, Dodabetta $(2,590 \mathrm{~m})$, Tamil Nadu, 8 Oct. 1993, M. Iwasa; 3ð, Ootakamund (1,900 m), Tamil Nadu, 9 Oct. 1993, M. Iwasa; $3 \widehat{\partial}$, Gudalur (1,400 m), 
Tamil Nadu, 9 Oct. 1993, M. Iwasa; 1 ऽ, Mysore, Karnataka, 12 Oct. 1993, M. Iwasa; 1 ऽ, Nandi Hills (1,490 m), Bangalore, Karnataka, 14 Oct. 1993, M. Iwasa.; 1ð, Joshipur (400 m), Orissa, 25 Sept. 1993, M. Iwasa.

Distribution. Oriental Region, Russia, South Korea and Japan.

Sepsis lateralis Wiedemann, 1830

Sepsis lateralis Wiedemann, 1830, Auss. zweifl. Ins., 2: 468.

Specimens examined. $5 ð$, Coonoor $(1,400 \mathrm{~m})$, Tamil Nadu, 7 Oct. 1993, T. Hayashi; 1§, Mysore, Karnataka, 12 Oct. 1993, M. Iwasa.

Distribution. Widely distributed in the Oriental and Afrotropical Regions, Mediterranean Subregion and New Guinea.

Sepsis nitens Wiedemann, 1824

Sepsis nitens Wiedemann, 1824, Analecta Ent.: 58.

Specimens examined. 1 1 , Astrang, Orissa, 28 Sept. 1993, M. Iwasa;6ð, Bangriposhi (380 m), Orissa, 24 Sept. 1993, M. Iwasa; 4ðૈ, Joshipur (400 m), Orissa, 25 Sept. 1993, M. Iwasa.

Distribution. Oriental and Australasian Regions.

Sepsis thoracica (Robineau-Desvoidy, 1830)

Micropeza thoracica Robineau-Desvoidy, 1830, Essai Myodaires: 742.

Sepsis thoracica: Duda, 1926, Annl. naturhist. Mus. Wien, 40: 37.

Specimens examined. $5 \widehat{\jmath}$, Dodabetta $(2,590 \mathrm{~m})$, Tamil Nadu, 8 Oct. 1993, M. Iwasa; 1ð, Ootakamund (1,900 m), Tamil Nadu, 9 Oct. 1993, M. Iwasa; $1 \delta^{\curvearrowright}, 1 \%$, Gudalur (1,200 m), Tamil Nadu, 6 Oct. 1993, M. Iwasa; 3ð, Mudumalai National Park, Tamil Nadu, 3-4 Oct. 1993, M. Iwasa; $1 ð$, Nandi Hills (1,490 m), Bangalore, 14 Oct. 1993, M. Iwasa; $1 ð$, Mysore, Karnataka, 12 Oct. 1993, M. Iwasa.

Distribution. Widely distributed in the Oriental, Palaearctic and Afrotropical Regions.

Sepsis suwai Iwasa, 1982

Sepsis suwai Iwasa, 1982, Kontyû, 50: 604.

Specimens examined. $28 \hat{\gamma}, 5 q$, Dodabetta $(2,590 \mathrm{~m})$, Tamil Nadu, 8 Oct. 1993, M. Iwasa; $3 ð, 5 q$, Gudalur $(1,200 \mathrm{~m})$, Tamil Nadu, 6 Oct. 1993, M. Iwasa; $1 \delta^{\star}, 1 q$, Ootakamund (1,900 m), Tamil Nadu, 9 Oct. 1993, M. Iwasa.

Distribution. India (Tamil Nadu).

Australosepsis frontalis (Walker, 1860)

Sepsis frontalis Walker, 1860, J. Proc. Linn. Lond., Zool., 4: 163. 
Australosepsis frontalis: Zuska, 1968, Acta ent. bohemoslov., 65: 472.

Specimens examined. $4 \widehat{\delta}$, Astrang, Orissa, 28 Sept. 1993, M. Iwasa; 1ð઼, Joshipur (400 m), Orissa, 25 Sept. 1993, M. Iwasa; 3ð, Gudalur (1,200 m), 6 Oct. 1993, M. Iwasa; 1 5 , Mudumalai National Park, Tamil Nadu, 3 Oct. 1993, M. Iwasa.

Distribution. Widely distributed in the Oriental Region and New Caledonia.

Australosepsis niveipennis (Becker, 1903)

Sepsis niveipennis Becker, 1903, Mitt. zool. Mus. Berl., 2: 143.

Australosepsis niveipennis: Hennig, 1941, Arb. morph. taxon. Ent. Berl., 8: 146.

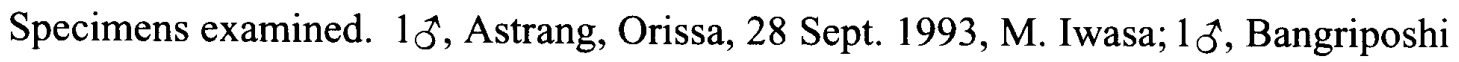
(380 m), Orissa, 25 Sept. 1993, M. Iwasa; 3ð, Gudalur (1,200-1,400 m), Tamil Nadu, 6-9 Oct. 1993, M. Iwasa.

Distribution. Widely distributed in the Oriental, Afrotropical and Australasian Regions.

Dicranosepsis bicolor (Wiedemann, 1830)

Sepsis bicolor Wiedemann, 1830, Auss. zweifl. Insekt., 2: 468.

Dicranosepsis bicolor: Zuska, 1970, Acta ent. bohemoslov., 67: 50.

Specimens examined. 3ð, Bangriposhi (380 m), Orissa, 26 Sept. 1993, M. Iwasa; 1ð, Ghatgaon, Orissa, 27 Sept. 1993, M. Iwasa; $8 ð$, Bandipur (900-1,200 m), Karnataka, 5 Oct. 1993, M. Iwasa; 7ð, Nandi Hills (1,490 m), Bangalore, Karnataka, 14 Oct. 1993, M. Iwasa; 5ð, Gudalur (1,400 m), Tamil Nadu, 9 Oct. 1993, M. Iwasa; $ð$, Mudumalai National Park (900 m), Tamil Nadu, 4 Oct. 1993, M. Iwasa; $1 \delta^{\jmath}$, Wynad National Park (720 m), Kerala, 11 Oct. 1993, M. Iwasa.

Distribution. Widely distributed in the Oriental and Australasian Regions.

Dicranosepsis distincta Iwasa et Tewari, 1990

Dicranosepsis distincta Iwasa et Tewari, 1990, Jpn. J. Ent., 58: 795.

Specimens examined. $4 ð, 1$, Bangriposhi (380 m), Orissa, 26 Sept. 1993, M. Iwasa; 1ð, Ghatgaon, Orissa, 27 Sept. 1993, M. Iwasa.

Distribution. India (Madhya Pradesh and Orissa).

Dicranosepsis prominula Iwasa, 1994

Dicranosepsis prominula Iwasa, 1994, Jpn. J. sanit. Zool., 45: 59.

Specimens examined. 6‡, Bangriposhi (380 m), Orissa, 26 Sept. 1993, M. Iwasa; 6ðึ, Ghatgaon, Orissa, 27 Sept. 1993, M. Iwasa; 4ð̋, Mudumalai National Park (900 m), Tamil Nadu, 4 Oct. 1993, M. Iwasa.

Distribution. Sri Lanka and India (Orissa and Tamil Nadu). New to India. 


\section{ACKNOWLEDGEMENT}

We wish to express our sincere thanks to Dr. S. Shinonaga (Tokyo Medical and Dental University) and Dr. K. Kamimura of (Toyama Medical and Pharmaceutical University) for giving us an opportunity to study the Sepsidae in India. We are much grateful to Drs. $\mathrm{H}$. Kurahashi and T. Hayashi of the National Institute of Health; Prof. H. Shima of Kyushu University; Prof. D. Kaul of Allahabad University for their generous help during the survey. Our thanks are also due to Prof. K. Hori of Obihiro University of Agriculture and Veterinary Medicine for his continuous encouragements.

\section{REFERENCES}

Brunetti, E. (1909): New Oriental Sepsinae. Rec. Ind. Mus., 3: 343-372.

Duda, O. (1926): Monographie der Sepsiden II. Ann. Naturhist. Mus. Wien, 40: 1-110.

Iwasa, M. (1982): A new species and some records of Sepsidae from India (Diptera). Kontŷu, 50: 604-609.

Iwasa, M. (1984): The Sepsidae from Nepal, with descriptions of eight new species (Diptera). Kontyû, 52: 72-93.

Iwasa, M. (1989): Taxonomic study of the Sepsidae (Diptera) from Pakistan. Jpn. J. Sanit. Zool., 40, Suppl.: 49-60. Iwasa, M. and R. R. Tewari (1990): Two new species of the genus Dicranosepsis Duda from India (Diptera, Sepsidae).

Jpn. J. Ent., 58: 794-798.

Iwasa, M., J. Zuska and A. L. Ozerov (1991): The Sepsidae from Bangladesh, with description of a new species (Diptera). Jpn. J. Sanit. Zool., 42: 229-234.

Iwasa, M. and N. Jayasekera (1994): The Sepsidae from Sri Lanka, with description of a new species (Diptera). Jpn. J. Sanit. Zool., 45: 57-62.

Iwasa, M. (1994): Two new species of the genus Meroplius Rondani (Diptera, Sepsidae) from the Oriental Region. Jpn. J. Ent., 62: 161-166.

Ozerov, A. L. (1992): On the taxonomy of flies of the family Sepsidae (Diptera). Bull. Moscow Soc. Naturalists, Biol. Ser., 97: $44-47$.

Zuska, J. (1968): Diptera from Nepal. Sepsidae. J. Nat. Hist., 2: 131-136.

Zuska, J. (1974): Asian Themira (Diptera: Sepsidae): Descriptions of two new species and distributional notes. Proc. Entomol. Soc. Wash., 76: 190-197.

Zuska, J. (1977): Family Sepsidae. In: A Catalog of the Diptera of the Oriental Region (ed., Delfinado, M. D. and D. E. Hardy), Vol. 3, pp. 174-181. The University Press of Hawaii, Honolulu.

\section{摘 要 \\ インドのツヤホソバエ類抢よび 1 新種の記載（双翅目）}

1987年と1993年に行われたインド亜大陸における双翅目昆虫の調査において採集された インドのツヤホソバエ類を調ベ, 1 新種 Meroplius maximus Iwasa, n. sp. を記載し, 3 新記録種 Meroplius elephantis Iwasa, Perochaeta hennigi Ozerov, Dicranosepsis prominula Iwasa を含む 7 属 18 種を記録した。新種の Meroplius maximus Iwasa, n. sp. は, M. beckeri (De Meijere) とM. elephantis Iwasaに類似しているが, 雄の前脚腿節の棘や剛毛の形状および雄交尾器の surstylus の前方に突起を有することなどによりそれらと明確に区別できる. 